Bert Van Herck

New England Conservatory

Boston

United States of America
UDC 78.071.1 Saariaho K.

doi $10.5937 / \mathrm{ZbAkU2109155H}$

Scientific review

\title{
Spatiality as Creativity in the Music of Kaija Saariaho - a Reflection with a Focus on Lichtbogen
}

Abstract: In this article Saariaho's music - with a focus on Lichtbogen- is explored from the perspective of spatiality. First, Saariaho's connection with Finland is discussed and in particular how Finnish space and time have influenced her music.Together with space, there is the relation between time and light. In fact, the creative process by Saariaho is strongly influenced by visual experiences. The title of Lichtbogen refers to the Nordic lights, and therefore it is an interesting example.

In her article on similarities between architecture and music, Saariaho defines with great clarity her music: "Capturing time and giving it form." In this phrase she connects the aspect of time and space with musical form. Understanding how Saariaho'sconception of musical form brings the concept of a multidimensional network to the discussion. Saariaho developed this concept for Verblendungen, and the same principle has been used for an analysis of Lichtbogen. This analysis is not a score analysis, instead, it is based on the listening experience of several recordings. As Saariaho is concerned with the perception of her music, a listening-based graphic analysis is proposed based on listening. It captures an illuminating perspective on the form of Lichtbogen. Given the importance of timbre in Saariaho's music, and the way how timbre and form are connected, the question of her relation with spectral music is unavoidable. Saariaho lived in Paris during the ' 80 s, when early spectralism made important developments. And her music is indeed deeply influenced by the spectral approach in many ways. However, there are differences, especially regarding her attitude towards musical form. Finally the discussion about space is taken to the perspective of electronics and how they contribute to the expression of space. In Lichtbogen, the amplification is used to make those sounds on the threshold of audibility audible, and the reverb is used to create virtual spaces. The concept of space is integrated in the composition itself. In conclusion, the concept of space is central to Saariaho's creativity. This connection is approached in this article from various perspectives.It illustrates how important the space is, in connection with time and light, in Saariaho'scompositional work.

Keywords: Kaija Saariaho, spatiality, Nordic Music, spectralism, Lichtbogen. 


\section{Saariaho and Nordic Music}

The fact that Kaija Saariaho (1952) is a Finnish composer is quite well-known. Saariaho never hesitated to talk about her home country. And as her music received more and more international recognition, her connection with Finland has remained strong, even though she has been living in Paris for several decades. One might wonder what the reasons are for such a strong connection. What is it that ties Saariaho so strongly to her native country? Reflecting on time and light in her music, Saariaho remarks:

Often people mention the notion of time in my music. Without doubt, this must be related to my culture and the light in my country. During the winter, it is very dark in Finland. When the spring arrives, it is the opposite, the sun doesn't go down anymore. The experience of Nordic time can be very painful. It is extremely slow. This has marked quite strongly my bodily and mental awareness. ${ }^{1}$ (Saariaho, 2013: 216)

The claim that the experience of Nordic time has shaped Saariaho's awareness, and as such has had a significant influence on her music seems obvious. Indeed, her music breathes the stillness and vastness of the Nordic landscapes and while listening to her music we almost sense these landscapes of her native country. Might this be a proposition that we accept all too easily?Nordic landscapes have an otherworldly mythic appeal, thatoften resultsin an experience of time that is labeled as suspended time. Tim Howell pointed to these clichés and mentioned: „'a sense of stillness', 'the power of quietude', 'atmospheric', 'meditative', 'contemplative'and so on, have become something of a mantra for Nordic new music" (Howell, 2014: 356). And he observes that the sense of time is related to the experience (or lack) of light: „Somehow, it has become a truth universally acknowledged that any composer born in a Nordic country must be in need of more light. There is a fundamental preoccupation with matters of darkness and light amongst North-European composers which affects their perception of time" (Howell, 2014: 356). It is worth to take note that the article quoted here focuses on the music of Magnus Lindberg, but when describing these general Nordic characteristics, Tim Howell explicitly refers to Saariaho:

The significance of light for the inhabitants of this region cannot be underestimated and this has been confirmed by a number of leading composers when interviewed about their work. Of Lindberg's generation, KaijaSaariaho (b.1952) is a particularly interesting example; she still feels strongly affected by issues of light and dark, suggesting that they are deeply rooted in her psyche, despite her having lived in Paris for some 30 years or so. (Howell, 2014: 357)

1 All quotations from texts in the French language, have been translated by the author. 
It should be clear that the aforementioned clichés are in the case of Saariaho not cheap labels, they actually do represent her lived experience. Growing up in Finland has profoundly influenced her, and that is indeed the lens through which she experiences the world. That might be the reason why she often talks about her home country. It is undeniable that Saariaho's music is almost a perfect example of the so-called Nordic features. Her music features long passages where time is passing without much or any articulation, suggesting a vast landscapethat is both impressive and intimidating. The music is established by haunting sounds that appear and evolve without being clearly defined as well as motives that create fluctuating textures.

\section{Visual experience as inspiration}

While the focus so far has mostly been on time, Saariaho continues the aforementioned quotation with emphasising the importance of light: „Time, that is light: light indicates the time, gives it rhythm, influences nature. I always need daylight when I work. I cannot compose during the night. For me, each instrumental sound has a different intensity of light. The more the light is white, the more the spectrum is pure" (Saariaho, 2013: 216). Therefore, it is clear that not only time and sound, but also light and sound are strongly connected. While this refers back to the clichés about Nordic music - time and light are indeed connected - the visual aspect of light has another connotation that is quite important to Saariaho's working method.

From her youth, Saariaho is influenced by visual impulses, and she even mentions smells in relation to music as she recalls that Paavo Heininen, while a student, had asked her to focus on instrumental music:

One turning point was when Paavo told me not to write any more vocal pieces - 'it's too easy for you - now you'll concentrate on instrumental music'. [...] But transferring that energy to instrumental music, it actually brought me back to my childhood perception of music, which was so full of smells and colours. And that opened up my music enormously. (Howell, 2011: 7)

And not only as a child, also later on regarding her choices for a profession, Saariaho's talent for visual arts was obvious:

When I spoke to my parents about wanting to be a composer, my father was very angry. [...] I had visual talents, for drawing, etching, sketching - I would spend Sundays at his office drawing plans for houses, for buildings - and he thought I should be an architect. That made sense for him. It was craziness instead to try something that there was no proof I was any good at. (Howell, 2011: 5) 
This connection with the visual arts is mentioned because it is still important to Saariaho: Verblendungen (1982-84) is inspired by a brush stroke with high initial energy, gradually fading out. The programme note for Nymphéa (1987) contains the following:

During the composition the images took form in my mind: the symmetrical structure of the waterlily, the broken symmetry then transformed by the ripples of waves. Different interpretations of the same image, in different dimensions; on one hand the one-dimensional surface with its structure and colours, on the other hand the perception of forms, dimensions, and different materials - a white waterlily fed by a vase underwater. (Saariaho, 2013: 279)

Amers (1992) is a metaphor of a ship passing from one sign to another where the soloist performs the role of the ship and the orchestra depicting a grey landscape. This image of a ship navigating through the waves was very present during the composition of Amers (Saariaho, 2013: 201).

These are just a few examples of how pervasive the visual influence is on Saariaho's musical inspiration. Lichtbogen is no exception to this as Saariaho reveals in the programme note:

Lichtbogen (arches of light) finds its origin in my experience of the phenomenon of Aurora Borealis. During the time I started working on this piece, I witnessed this in the Arctic sky. While observing the movements of these silent lights in the immense black skies, the music started to find its form and language. What is the relation - does it even really exist? between the natural phenomenon and my music? I cannot tell. (Saariaho, 2013: 274)

This statement brings back the presence of the Nordic influence. Clearly this influence is important as the Northern lights have found their way into the title of the composition. However, the influence of visual impressions is broader than just Nordic. Saariaho is very sensitive to light and visual aspects in general, it just so happens that Lichtbogen is inspired by this particular Nordic phenomenon. The connection between visual influences and musical creativity - broadly defined - is quite specific for Saariaho. This might seem to hint at synesthesia, however Saariahonever mentioned this, and neither did she ever talk about a one-to-one relation between pitch and colour as for example Messiaen did. Perhaps synesthetic congruency - typically seen as a case of crossmodal correspondences - is a better concept. They are not oneto-one correspondences but should be thought of as „,band“" correspondences ${ }^{2}$. However

2 More on the topic of crossmodal correspondences and synesthesia can be found in Crossmodal correspondences: A tutorial review by Charles Spence, as well as in Audiovisual cross-modal 
crossmodal correspondences are considered to be shared correspondences and Saariaho seems to express her experiences as unique, which would rather indicate synesthesia ${ }^{3}$. In any case, Saariaho does acknowledge that some aspect of a visual impression informs her music - not as a translation into music, but on a deeper level, such as for example the structure of the composition. Thereforevisual stimuli help Saariaho to guide her creativity. In that sense the visual experiences reinforce her musical imagination.

All of this is a bit vague, and it is difficult to clearly pinpoint how this influence is materialised in the music. Saariaho is well aware of this. And when mentioning the influence of visual experiences on her music, she has the clarity to question the relevance for the listener. Yet this connection is very important to her. Not for the sake of analysis to explain her compositions but for herself, how she is able to forge her imagination in the process of creation: „Yes, these associations are very present, even though I'm not looking for them specifically. It is how I imagine things. Obviously our language is rather limited in trying to convey all of this. I feel disabled to talk about it, because when one starts talking about this one has to separate things that are impossible to separate" (Michel, 1994: 8).

\section{"Capturing Time and Giving it Form"}

The previous paragraphs gave a general idea of how Saariaho thinks about her creativity. Now, the question is: how does she conceive of music specifically; what is her imagination focused on during the process of composition? Again, the concept of space and timewill guide us.In the conference Matter and Mind in Architecture (August 1997), Saariaho contributed with a presentation including reflections on the similarities and differences between music and architecture. Her ideas in the article: „Matter and Mind - between Architecture and Music“ (originally published in 1998) connect seamlessly with the observations about time made above. Might it be a coincidence that the conference was on architecture - recalling that her father wanted her to become an architect? In any case, Saariaho goes on to describe with great clarity what she thinks about composition. Perhaps the lack of musical technicalities - in the light of the comparison to architecture - brings out a laser sharp focus on what matters most to her: „In Music, time is matter, and therefore, to compose is to explore time in all its aspects: regular time, irregular time. Composing is capturing time and giving it form" (Saariaho, 2013: 184).

Especially the last phrase, as short as it is, has been quoted often. It does indeed point to the importance of time, and how time is used - captured - to create musical correspondences in the general population by Cesare Parise and Charles Spence. In particular, the difference between synesthesia and different types of crossmodal correspondences are clarified.

3 The topic of crossmodal correspondences versus synesthesia in the case of Saariaho is partially speculation as there is not enough information available. Her experience of uniqueness might not be accurate, even though it can be accurate of how she feels about it. 
form. Therefore, it connects two essential aspects: time and musical form. These aspects are linked together and are immediately connected in Saariaho's musical creativity. In her article, she proposes two different ways how this can be realised: 1. Music becomes space - this is the expression of spirit, the imagination - and 2 Pulsations (such as for example, a heartbeat) are the physical expressions; they are considered as more primitive by Saariaho. One should consider these two points more as the extremes of a sliding scale. Rather than two binary positions, there is an axis along which the music can move (similar to her sound-noise axis for timbre ${ }^{4}$ ). With these clear concepts, Saariaho conceives of her music. Noteworthily, the clarity of this concept is very flexible to apply, allowing her to work intuitively. Saariaho freely shapesmusical forms, giving expression to the way she imagines to capture time.

One might wonder how these concepts can be applied and how that actually works out. In the aforementioned article, Saariaho gives a beautiful example with a description of how she experienced the viewing of a Japanese garden ${ }^{5}$ :

In Tokyo, once I understood how traditional gardens are conceived,and how much the movement of the eye is planned, I immediately understood the connection between architecture and music:the two art forms select and present materials, let them develop,give them form, create new contrasts, and forge new relations between the materials. Once objects are disconnected from their daily life, houses, gardens, bridges,and other architectural objects, they can become the focus of contemplation, exactly as the Japanese do with their gardens. (Saariaho, 2013: 185)

This is quite revealing for how Saariaho envisions musical form to act while listening. Form is dynamic, not a static structure. This dynamic approach gives her the freedom to let materials develop, or to create contrasts, or to forge new materials. The goal of form - and of her music - includes contemplation, which echoes her earlier comment that music is in the realm of the spirit, the imagination when music becomes space. This obviously is not a technical approach to form, but it does describe with beautiful clarity what Saariaho aims for when composing. To compose is about the passing of time and how to shape this flowing.

4 The use of the sound-noise axis in Saariaho's music is discussed in „La transparence du signe“ by Damien Pousset.

5 The example of the Japanese garden given by Saariaho is interesting in comparison with the earlier mentioned influence of Nordic landscapes. The Nordic influence (which is more than the landscapes only) is part of Saariaho's way of being. She fully embraces her identity as a Nordic person, but it is not chosen. It is given to her as part of the culture where she grew up. On the other hand, the example of the Japanese garden is for Saariaho a conscious choice: she takes the organisation of the Japanese garden as a model for her own musical forms. Although this is not part of her upbringing, it resonated with her strongly. The model of the Japanese garden is a rational aspect of her thinking about form - even if she applies it in intuitive ways. 
We can conclude that Saariaho's definition of music Capturing time and giving it a form connects her particular sense of time together with musical form. It describes how fundamental time is in Saariaho's compositional process, and how time structures her compositions. Saariaho's experience of time is indeed at the heart of her musical work.

\section{Parameters and Musical Discourse}

If Saariaho's music is like a Japanese garden, how are we guided through it? What is the form and what does she point our attention to? Listening to Lichtbogen, Saariaho ,guides“ our ear through the piece, from a pure F\# in unison at the beginning until a completely distorted noisy F\# at the end, broken into a wide tessitura. But the path from the beginning to the end is not a simple gradual transformation. The form is far more complex.

In her article Timbre and Harmony (originally published in 1987) Saariaho explains in detail the form of Verblendungen from 1982. She proposes what she calls a multidimensional network where different parameters interact. Saariaho has different graphs for each parameter over the course of the composition. However, these are not traditional parameters such as we know from serialism- Saariaho wants her structures to be perceivable - these are audible parameters ${ }^{6}$. The parameters that she used in the composition of Verblendungen are: polyphony, the range of the tessitura, dynamics, homophony, the speed of the harmonic rhythm, and the relation between orchestra and tape. Perhaps 'parameter' is not the best word to describe these categories. These socalled parameters are indeed very perceivable and have an immediate impact on the perception of the musical form.

So what are the audible parameters of Lichtbogen that are guiding our listening? As Saariaho did not reveal this in her writings, we will have to find parameters that are meaningful categories for our listening experience of Lichtbogen. For this analysis we propose the following parameters: 1. the range of the tessitura (indicated in green in the analysis); 2. the distortion of sound or noise (indicated in blue in the analysis); 3. the activity or motion (indicated in red in the analysis). These parameters seem the most salient to the listening experience and have been included in the graphic analysis in figure No. 1 below $^{7}$.The recordings used to make this analysis are: Avanti Chamber

6 The author followed here the way Saariaho describes parameters. The discussion about whether or not parameters are perceivable is obviously much more complex than the simple binary situation that is assumed here. Let us summarise Saariaho's position by referring to the influence of spectral music (which is discussed below). Saariaho adheres a holistic approach of sound as is the case for the spectral composers, in opposition to a focus on composing with parameters as the building blocks of a composition which is the principle used by (post-)serial composers.

7 This analysis has been done by listening. This is to honour the importance Saariaho has for the perception of her musical form (in contrastto structures on paper). However, as the timings of the three recordings (listed in the references) used to make this analysis vary significantly, the measure numbers referring to the score are indicated in the graphic analysis. 
Orchestra, conducted by Jukka-Pekka Saraste; Endymion Ensemble, conducted by John Whitfield both from 1989; and a more recent recording from 2012 by the Avanti Chamber Orchestra, conducted by Hannu Lintu.
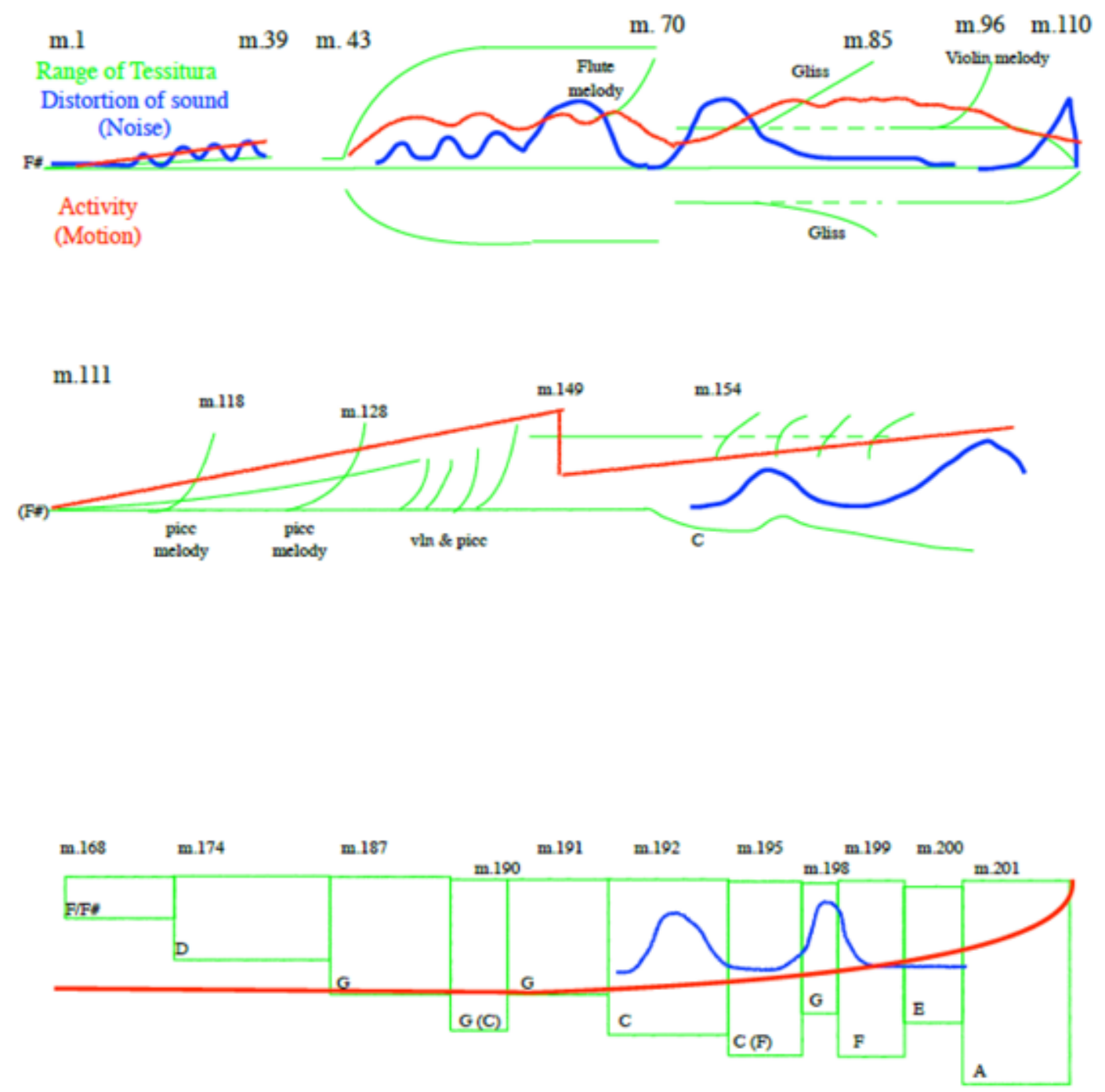
m.1

Range of Tessitura

Distortion of sound (Noise) $\begin{array}{lll}\mathrm{m} 39 \mathrm{~m} .43 & \mathrm{~m} .70\end{array}$

m. $70 \quad m 85 \quad m .96 \quad \mathrm{~m} .110$

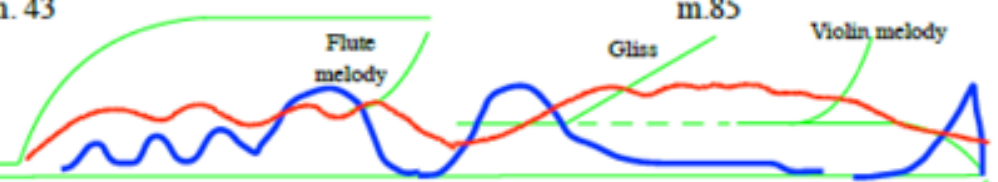

Activity

(Motion)

m.111
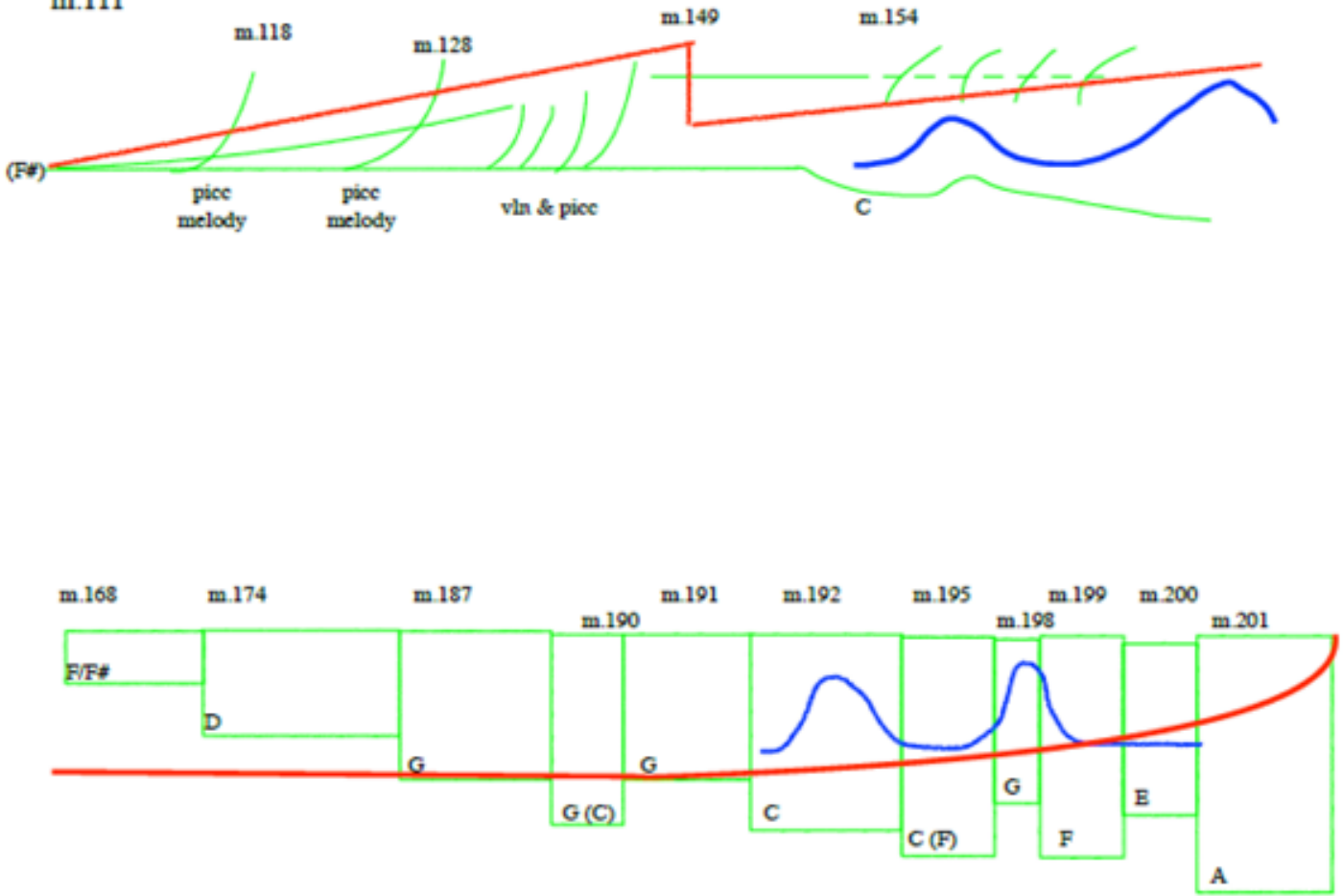

Figure 1. Graphic analysis of Lichtbogen. 
The green lines indicate the range of the tessitura. The green boxes indicate a strong presence of harmonic rhythm (with the bass note in brackets). ${ }^{8}$ An interesting pattern is the gradual building up of activity that is suddenly dropped. This happens four times: from m.111-149, from m.149-168, from m.168-203, and finally from m.204-243. In m. 243 it is especially powerful as it coincides with an equally important drop of noisy sounds, and a reduction of the range to a single note in the high registeras well as the end of a harmonic rhythm that gave a sense of movement. This leads to an extremely evocative section from m.243-289 when the upper register sounds very thin and has no support but a soft low bass note. There are no harmonies, all movement seems to have stopped. Time seems to have come to a halt.

Figure 2 shows a sonogram of the music from measure 225-267. In the middle of the figure, the change to the static music with the single bass note is easy to see. It is noteworthy to notice how the distorted sounds in the static passage are very noisy indeed and almost to extent that they hide the static characteristic of this passage. The sonogram is from the performance by the Avanti Chamber Orchestra conducted by Jukka-Pekka Saraste.

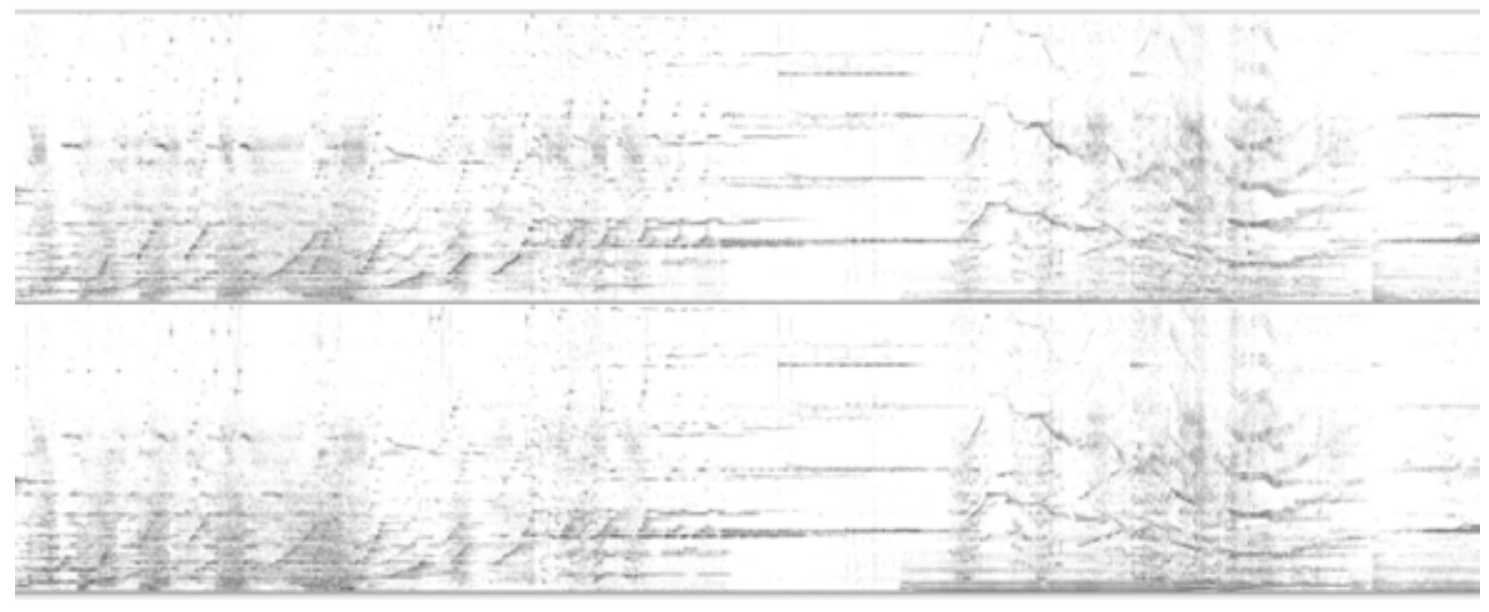

Figure 2. Sonogram of m. 225-267 of Lichtbogen. (c) 1986 Edition Wilhelm Hansen, Helsinki. Reprinted by Permission of Hal Leonard Europe Ltd.

The most distorted sounds are closer to the end which seems to be a contrast to the beginning: a distorted sound instead of a pure pitch and also a wide tessitura instead of the single pitch at the beginning. Another remarkable feature is the appearance of F\# 8 Colours available only in online edition of the journal (Editor's Note). 
throughout the composition: this note is prominent in the opening and the music returns back to the same note in $\mathrm{m} .110$ and stays then as bass note until $\mathrm{m} .150$. With the sudden drop in activity in $\mathrm{m} .168$ the F\# returns as bass note, briefly this time, but will return in the extreme high register as prominent pitch from m. 243-265. And at the end the F\# returns once again, distorted by the whispering of the flute player.

The graphic analysis is quite general, but the aim is to give an overview of the form, and how Saariaho is guiding us through her music - similar to the movement of the eyes discovering a Japanese garden.

\section{Timbre and the Influence of Spectral Music}

Timbre is a crucial element in shaping the form in Lichtbogen. It is perhaps the most important characteristic that Saariaho focuses on in her compositions. The fact that she is generally considered a spectral composer should not surprise us: the music speaks for itself. There is however a tension between this apparent fact that her music reveals, and the hesitation - or refusal? - on Saariaho's part to acknowledge the label of spectralism. This is intriguing.

To be clear, Saariaho acknowledges the influence by Gérard Grisey and Tristan Murail. There is no question that she is influenced by the spectral movement. But how profound is this influence, and how much is the overlap between her music and the music of the spectralists? A first similarity is the attitude towards composition. The spectralists wanted to approach music in a positive way, not in a negative way by avoiding taboos - such as the serial technique was based upon'.Saariaho has a similar viewpoint. She was unconvinced by the increasing complexity of (post-)serialism: „These guys were drawing those unbelievable diagrams on the blackboard, systems, and interactions, and all of that - and what did you hear of it in the music? All of that complexity, for what aural result?" (Howell, 2011: 9).On the other hand, Spectralism was immediately very appealing to her: „It sounded so fresh, it was just unbelievable. We had had this post-serial education, where octaves are forbidden even in an orchestral context, and Grisey's and Murail's music just sounded so good.“(Howell, 2011: 8).

9 There are several articles by Murail and Grisey explaining the spectral attitude. Questions de cible by Tristan Murail is an excellent example for a detailed and comprehensive description of the spectral attitude. This entails thinking in terms of continuity instead of discrete (everything is linked together); a global approach to sound, seeing it as a whole and not segmented in parameters of sound; thinking in functionality and not in combinatorial organisation; being concerned about the relation between concept and perception. Spectralism is concerned with an holistic approach to sound. 
A second similarity Saariaho shares with spectralism is the importance of perception as part of the compositional process.Grisey and Murail had ambitious goals when they proposed to develop a new kind of music based on the perception of sound ${ }^{10}$. This was radical, and this attitude was fully embraced by Saariaho. She was involved at research at IRCAM after her arrival in Paris, and she did collaborate with Stephen McAdams resulting in a paper "Qualities and Functions of Musical Timbre“ published in 1985. A fundamental aspect of spectralismthat plays with our perception, is the ambiguity between timbre and harmony. This topic is very much at the centre of Saariaho's work:

In my compositions for acoustic instruments in combination with synthesised sounds,I am fascinated by the ambiguity between harmony and timbre. In that case, I use the same structure (that always is derived from the analysis of an instrumental sound) for the harmonic progressions as well as for the synthesis. (Saariaho, 2013: 181)

It was the electronic studio that made the connection with research and perception possible. Without the studio, the analysis of sound would not have been possible, and our understanding of timbre would not be the same. While most spectral composers did not focus on composing tape music, they all did rely heavily on the work done in the studio. New tools were being developed in the studio that applied the newly discovered aspects of sound and timbre. This is the revolution that spectral music wanted to bring: the scientific research changed our understanding of sound, and based on these scientific facts new tools for composition are being developed. Tristan Murail for example was - and still is - very active in the programming of OpenMusic (originally called PatchWork). Saariaho was similarly involved and used extensively the software CHANT, a software programme for sound synthesis.

With these remarks in mind, it seems that Saariaho is indeed a spectral composer. Living in Paris, working at IRCAM, Saariaho is at the centre of spectral developments in the '80. Yet, there are differences. In Saariaho's own words:

But Grisey's approach did not match mine. I became his friend, but he had a very systematic way of analysing his sonograms; his orchestration was mathematical, and my work is not at all systematic or mathematical. [...] I don't want the machine to compose for me - I like composing! I didn't have the ambition to create a programme that would do something complex

10 The focus on perception by the spectral composers is often seen as a critique on the complexity of serial structures. It should be clear that the audibility of the method of composition is not necessarily a criterion for artistic validity. This is true for serialism, but also for earlier music such as for example complex polyphonic structures in the renaissance. However, the focus on perception by the spectralists was refreshing and did lead to a different approach to composition. 
and wonderful, because I want to do the complex and wonderful myself' (Howell, 2011: 11)

So, while Saariaho had similar aesthetic goals in mind, her mind works in a different way. Saariaho has a strong sense of intuition and the computer is a tool - an essential tool indeed - but the role of the computer needs to be limited for her creativity to flourish.

There is another difference as well, and that is the approach to musical form. For Grisey and Murail, form is the result of gradual transformations of sound. For them there is no difference between the sound material and the musical form, as one is the result of the other. The ideal for musical form is zooming into a single sound (through the sonogram) and to magnify all the internal life to the scale of form. There is no opposition between material and form. At least this is their ideal.

And these ideas are echoed by Saariaho: "For each piece, I construct the sound in the same way as I define the musical form - which itself depends on the sonic material" (Saariaho, 2013: 150).But at the time when Saariaho moves to Paris, it has become clear that early spectral music had a very predictable form. Too predictable, and it was a problem - especially those slow gradual transformations of sound. And indeed, in 1985 Grisey wrote Talea in which fast passagesareprominent. Spectralism needed the ability to incorporate fast tempi. And later on in the ' 90 spectralism would embrace forms that were much more dynamic, including sudden changes - quite dramatic in comparison with early spectral music. ${ }^{11}$

However, before these developments, in the '80 Saariahodeveloped her own approach to form. And while she embraced the connection between timbre and form, her method for developing form is different from the spectral ideal. Saariaho developed a multidimensional network to generate musical forms as discussed above in connection with Lichtbogen. Such a network includes different curves for different parameters. This allowed Saariaho to work directly on the level of form, and to control how the form would affect the listening (similar to the eyes exploring a Japanese garden). Form is not simply the result of the transformation of the sound material, form has its own independent evolution. ${ }^{12}$

11 More information on spectral techniques can be found in François Rose's article Introduction to the Pitch Organization of French Spectral Music (1996). Here detailed information is given about a limited number of selected compositions that are representative of the spectral approach. A few years later, in 2000, two issues of Contemporary Music Review were dedicated to Spectral Music, edited by Joshua Fineberg. These issues provide a wealth of information on Spectral Music including aesthetics and techniques, and is not limited to the French spectralists.

12 This topic has been discussed as an asymmetry between timbre and harmony by Eric Drott. This is an interesting perspective to the discussion of form and therefore is worth being quoted here: „At issue was the use of acoustic models to derive frequency structures at both 'microphonic' (timbral) and 'macrophonic (harmonic) levels, a technique pioneered by Grisey and Murail. Recourse to such models 
Perhaps this is an overstatement. After all, the form of early spectral music is also controlled by the composer. Grisey liked to compare his forms to the cycle of breathing (increase tension, release tension, relax). How to start and how many cycles to go through are beyond question artistic choices - even if the material and the form are connected. But the inclusion of parameters in the multidimensional network by Saariaho is a contradiction for the spectralists. Parameters are arbitrary distinctions of aspects of sound that cannot be separated.

Is this the reason for Saariaho not to call herself a spectralist? Perhaps. But while her music sounds very spectral indeed, and while she embracesmostaspects of spectralism, there is a different focus in her approach to form. While the spectralists see form as an extension of the internal life of sound, for Saariaho form is a dynamic field where several forces interact with each other. In the end, the realisation of form may not be very different, form is part of the compositional process with plenty of choices being made. But the attitude is different. Yet Saariaho's goal, to create a musical architecture based on timbre, seems to be very much in line with spectralism.

Finally it should be clear that in spite of these remarks on differences, Saariaho is usually considered a spectral composer. Her music is presented and discussed in the context of spectralism. As an example, Clara Foglia presented the compositional process of early works by Saariaho at the Spectralisms- 2 conference at IRCAM in June 2019. Her presentation was focused on the use of spectral techniques, and in particular the role of technologies that Saariaho used in creating a harmonic framework based on instrumental recordings. „The analysis of instrumental sounds allows me to construct spaces of timbres and microtonal harmonies, scales, modes that serve me to create a harmonic background and synthesised timbre against which the instrumental lines will appear" (Saariaho, 2013:157). This method to create harmonies starting with the analysis of timbres from recorded sounds is essential for Saariaho's music. And in that respect, Lichtbogen is a milestone: „In Lichtbogen, I found my own way to create harmony from the analysis of instrumental sounds“" (Michel, 1994: 17).

was salutary insofar as it offered novel means of connecting timbral and harmonic domains. The problem was that in privileging acoustic models, this approach established an asymmetry between these domains: the microstructure of spectra generated harmonies, but the macrostructure of harmonies never generated spectra. This one-way relationship between timbre and harmony represented for Saariaho an unwarranted limitation on compositional agency" (Drott, 2017: 265-266). 


\section{The Use of Electronics}

The importance of computers for Saariaho is obvious for the analysis of sound as well as the synthesis of sound. This is part of the compositional process and this aspect has been discussed above. The use of electronics in the performance of a piece serves a specific need for Saariaho. ,[...] This experience pushed me from early on to integrate the possibilities of amplification in my research. I wanted to bring forward some explorations of sound - that would not be audible or perceivable - in the way I wanted to hear them" (Saariaho, 2013: 205).This relates back to her fascination with timbre: she wants to make audible the sounds that are too soft to be heard, therefore Saariaho will use amplification. An example is the flute noises near the end in Lichtbogen: these sounds would be covered by the instrumental ensemble if they were not amplified. In this way Saariaho enriches the timbral palette and incorporates the soft and fragile timbres that are usually lost in performance. She considers this use of electronics as part of the orchestration: „In that way, the use of live electronics isformea way of orchestration, even if the transformations are sometimes barely audible, they are always an important part of the music" (Saariaho, 2013: 182).

While perception is at the heart of Saariaho's compositional work, she does indeed use subtle nuances. In Lichtbogen the electronics - besides the amplification - consist of harmoniser and reverb. The instructions are very detailed: she writes the amount in percentages. While the result is very subtle, the electronics are an essential part of the composition even though they are rarely prominent. While the electronics sometimes border on audibility, the result is a very convincing and effective use of live electronics. They do extend the sounds beyond the instrumental acoustics as a form of orchestration indeed.

But Saariaho reflects further in the previously mentioned article on the relation between architecture and music:

From my first concerts I became interested in the acoustics of the concert halls. The unsatisfactory experiences of my music projected in space pushed me to explore the amplification of the instruments. This gave me the opportunity to concentrate on aspects of sound that otherwise would be inaudible. For the same reasons, I often worked with electronic reverb as a way to create virtual acoustic spaces. (Saariaho, 2013: 187)

Here in this quotation, Saariaho connects the use of electronics with the evocation of space. Amplification makes a very close, intimate space audible; reverb is a tool to create virtual spaces. Both aspects are present in Lichtbogen. And, it now 
becomes clear that the use of electronics is for Saariaho another way to work on the aspect of space - yet another reminder of how central this concept is in her work.

From these observations, one might think that Saariaho has fullyembraced electronics in her work. To a large extent that is true, but she also has reservations. EarlierSaariaho was mentioned describing her desire for the act of composition in contrast to programming a computer to do the composition. Saariahohas indeed aneed for computers in her compositional process: „They allow us to analyse and understand the sound and perception that we have of it, as well as our capacity to distinguish different forms of texture and musical structures" (Saariaho, 2013: 206). But ultimately, these tools - as important as they are - remain tools.

Also in performance, Saariaho is concerned about how the electronics affect the interpretation. As a matter of fact, she feels a need for actual performers which explains her limited output of tape music (and most of it is quite early in her career). As she explains:

What is an interpretation? If I imagine a very good interpretation, it will be of course perfect from a technical point of view, but that is not all; in any case a machine would produce the most perfect performances. I expect from a performer that he understands my music. And only from that point on he can play, conduct, or sing with conviction. To understand means to integrate the vocabulary of a composer, first intellectually, next by learning to read the phrases built with that vocabulary, and finally the meaning of these phrases. And what adds the performer while playing the music he has assimilated? He adds his experience of this music, and that is his important contribution that elevates his performance to an interpretation instead of a reading. (Saariaho, 2013:147)

This sensitivity towards performance is stunning. It forces Saariaho to include electronics to manipulate the sense of space, and at the same time it forces her to develop a deep appreciation for the relation of the performer with her music. And as a result she accepts the limitation of her role as a composer by giving the freedom of interpretation to the performer: „I'm thinking in particular of two recordings of my piece Lichtbogen, one realised by the Avanti ensemble!, the other by the Endymion Ensemble: how different can the same score be read by different musicians... ${ }^{13 * 6}$ (Saariaho, 2013: 189).

13 These two recordings are very different indeed: the duration of Lichtbogen by the Endymion Ensemble is 19 '27" whereas the recording by the Avanti Chamber Orchestra (conducted by Jukka-Pekka Saraste) has a duration of 16' 52 '. Only the comparison of the durations already indicates how different these two interpretations are. 


\section{Final Remarks}

In Lichtbogen there is a sense of space and time that becomes tangible.Even though this is particularly strong for Lichtbogen, it is a hallmark of most of Saariaho's music. This aspect of her music has been explored in various ways from different perspectives. It is remarkable how pervasive the concept of space is in her music. It is a fundamental aspect of her creativity.

A special example at the end of Lichtbogen adds a hidden dimension: the F\#distorted by the noise of the whispering flutist brings the listener to the end of the piece. The electronics make the inaudible sounds hearable as part of the ensemble but the text cannot be understood. In the score the text is written in IPA, probably for practical reasons but it also amplifies the mystery of the text.

The text is a poem by Henry Vaughan The World, in a French translation (from the collection La Poésiephilosophique by Louis Vax). Saariaho recounts:

I have used the sounds, in particular the consonants of the first verses of the French translation, for the recitation by the flute player ( $J^{\prime} a i v u$ l'Eternitél'autrenuit...). The poem depicts a staggering landscape, a land of light and infinite space; in this eternityof light and peace, time moves by hours, days, and years. I was astonished when I found this poem, because its atmosphere corresponded exactly with what I was hoping to express in my work. At the time of the very first ideas, I spent a December night in Lapland to observe the aurora borealis, and this experience illuminates the whole composition. When I found this poem of Vaughan, the composition was basically done, and only the end was not finished, although all planned out. Even if the public will never catch the signification of the whispered verses, it was important for me to use a text that was related to my music for the choice of the phonetic material. (Saariaho, 2013: 142-3)

Again a landscape, this time 'a land of light and infinite space' is the inspiration. It is anotherfitting example of how important the concept of space and light is to her creativity. But it might be misleading to think that Saariaho does not care about the public understanding the signification of these verses. She might not care about these verses be understood but only because the meaning of these verses have already been expressed in her music. She does care about her music being understood, she wants to communicate through her music: „Music is a language that enables us to transmit knowledge and feelings that otherwise would not be possible to be communicated" (Saariaho, 2013: 202). 
The need for expression is urgent for Saariaho, and she experiences this as a duty of her artistic life. „I cannot help but think that the artist should assume the role of spiritual guide. [...] As dramatic as it can seem to be, I think that artists today carry the profound heritage of humanity in the broadest sense" (Saariaho, 2013: 153). It is this task that Saariahohas taken upon herself, adding with her music her own perspective. And as a guide, she takes us - again - to other spaces: „But music also transports us in spaces that we otherwise would not know. It is this hidden dimension of music that makes me so attached to it, and that I - day after day - am ready to begin another day of work as difficult as it sometimes can be" (Saariaho, 2013: 215).

\section{REFERENCES:}

1. Avanti Chamber Orchestra, Jukka-Pekka Saraste. 1989. Lichtbogen. Finlandia, Fazer Music Inc.

2. Avanti Chamber Orchestra, HannuLintu. 2012. „Lichtbogen.“ In: Kaija Saariaho - Works for Orchestra. Helsinki: Ondine Oy.

3. Drott, Eric. 2017. „Saariaho, Timbre and Tonality“, In: Tonality since 1950 (eds. Felix Wörner, Ullrich Scheideler, and Philip Rupprecht). Stuttgart: Franz Steiner Verlag.

4. Endymion Ensemble, John Whitfield. 1989. Lichtbogen. Finlandia, Fazer Music Inc.

5. Fineberg, Joshua (editor). 2000. Contemporary Music Review, 19:2 \&19:3.

6. Foglia, Clara. 2019. „Verblendungen, Io, Solar: restructuration 'spectrale' des harmonies 'fonctionnelles' dans le développement de la formetéléologique." In: Conference Spectralisms-2, Paris IRCAM.Retrieved 13 $3^{\text {th }}$ March, 2021 from the World Wide Web

7. https://medias.ircam.fr $/ \mathrm{x} 4179 \mathrm{ef}$

8. Howell, Tim. 2011. „Meet the Composer - Kaija Saariaho in Conversation with Tom Service.“ In: KaijaSaariaho- Visions, Narratives, Dialogues (eds. Tim Howell with Jon Hargreaves and Michael Rofe) 3-14. Farnham, Surrey, England: Ashgate.

9. Howell, Tim. 2014. „Magnus Lindberg: Narratives of Time and Space,“ Contemporary Music Review, 33:4, 355-372.

10. Michel, Pierre. 1994. „Entretien avec Kaija Saariaho.“ In: Les cahiers de l'IRCAM Collection "Compositeurs d'aujourd'hui", 7-23. Paris: Editions IRCAM - Centre GeorgesPompidou.

11. Murail, Tristan. 2004. „Questions de cible.“Tristan Murail-Modèles\& Artifices, edited by Pierre Michel, 45-73.Strasbourg: Presses Universitaires de Strasbourg.

12. Parise, Cesare \& Spence, Charles. 2013. „Audiovisual cross-modal correspondences in the general population." In: Oxford Handbook of Synesthesia, edited by Julia Simner and Edward Hubbard, 790-815. England: Oxford University Press.

13. Pousset, Damien. 1994. „La transparence du signe.“ In: Les cahiers de l'IRCAM - Collection "Compositeursd'aujourd'hui", 7-23. Paris: Editions IRCAM - Centre Georges-Pompidou. 
14. Rose, François. 1996. „Introduction to the Pitch Organization of French Spectral Music,“ Perspectives of New Music, 34:2, 6-39.

15. Saariaho, Kaija. 1987. Lichtbogen. Helsinki: Edition Wilhelm Hansen.

16. Saariaho, Kaija. 2013. Le Passage des Frontières - Écritssur la musique.Paris: Éditions MF - Collection Répercussions.

17. Spence, Charles. 2011. „Crossmodal correspondences: A tutorial review,“ Attention, Perception, and Psychophysics, 73: 971-995.

\section{Prostornost kao kreativnost u muzici Kaije Sariaho - osvrt s fokusom na „Lichtbogen“"}

Apstrakt: U ovom članku, muzika Sariaho se - s fokusom na „Lichtbogen“ [Svetlosni luk] - istražuje iz perspektive prostornosti. Prvo se razmatra veza Sariaho s Finskom i posebno to kako su finski prostor i vreme uticali na njenu muziku. Zajedno s prostorom, postoji odnos između vremena i svetlosti. U stvari, na kreativni proces Sariaho snažno utiču vizuelna iskustva. Naslov „Lichtbogen“ odnosi se na nordijska svetla i zato predstavlja zanimljiv primer.

U svom članku o sličnostima između arhitekture i muzike, Sariaho veoma jasno definiše svoju muziku: „Hvatanje vremena i davanje mu oblika.“ U ovoj frazi, ona povezuje aspekt vremena i prostora s muzičkom formom. Razumevanje kako koncepcija muzičke forme kod Sariaho dovodi do preispitivanja koncepta višedimenzionalne mreže. Sariaho je razvila ovaj koncept za „Verblendungen“, a isti princip je korišćen za analizu dela „Lichtbogen“. Ova analiza nije analiza partiture, već se zasniva na iskustvu slušanja nekoliko snimaka. Pošto se Sariaho bavi percepcijom svoje muzike, predlaže se grafička analiza zasnovana na slušanju i tako pojašnjava formu dela „Lichtbogen“.

S obzirom na važnost tembra u muzici Sariaho i na način na koji su tembr i forma povezani, pitanje njene veze sa spektralnom muzikom je neizbežno. Sariaho živi u Parizu od 80-ih, kada su se desili važni pomaci u ranom spektralizmu. Na njenu muziku je umnogome uticao spektralni pristup. Međutim, postoje razlike, posebno u pogledu njenog odnosa prema muzičkoj formi.

Konačno, razmatranje prostora se se posmatra iz perspektivu elektronike i kako ona doprinosi izražavanju prostora. U delu „Lichtbogen“ se koristi amplifikacija kako bi se ti zvukovi na pragu čujnosti zapravo i čuli, a reverb za stvaranje virtuelnih prostora. Koncept prostora integrisan je u samu kompoziciju.

Sveukupno, koncept prostora je od ključne važnosti za stvaralaštvo Sariaho. Ovoj vezi se u ovom članku pristupa iz različitih perspektiva. On ilustruje koliko je u komponovanju Sariaho važan prostor, zajedno s vremenom i svetlošću.

Ključne reči: Kaija Sariaho, prostornost, nordijska muzika, spektralizam, „Lichtbogen.“ 